\title{
TRADITIONAL UKRAINIAN SONGS AS PERFORMED BY FOLK CHOIRS OF 'SLOBODA' UKRAINE
}

\author{
Vlada Rusina \\ vlada_musik@mail.ru \\ The National Academy of Sciences \\ of Ukraine
}

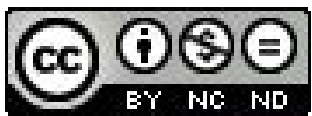

\begin{abstract}
In the context of the worldwide globalization processes the issues pertaining to the quest for national identity acquire a particular significance. This is true in the case of Ukraine as a newly-independent state in the establishment and consolidation phase.

In the conditions marked by a general obliteration of folk customs and traditions it is folk amateur choirs/gatherings (hurts) that often become vehicles of folk culture. This study presents rare records of traditional Ukrainian songs, some of them dating back to the $19^{\text {th }}$ century, which the author made in the course of several field trips.
\end{abstract}

Key words: folk customs and traditions, national identity awareness, song folklore, ballads, Ukraine.

\section{INTRODUCTION}

The Sloboda song folklore has attracted the attention of field researchers and scholars alike since the $19^{\text {th }}$ century. The pioneer works of prominent philologists O. Potebnya (Potebnya, 1887), P. Ivanov (Ivanov, 1907), M. Sumtsov (Sumtsov, 1918) et al. laid the academic foundations for further research into the ethnographic and folklore studies in the region. The musical aspects proper of the Sloboda song folklore do not seem to have received critical coverage until the 1990s, when the song collections with scores were first published and critically reviewed by V. Stupnitskiy (Stupnitskiy, 1929) and O. Steblyanko (Steblyanko, 1965). The peculiar plangent singing so typical of the Sloboda traditional singing style first became the subject matter of musicological studies made by O. Murzina (Murzina, 1995), V. Osadcha (Osadcha, 2001) et al. in the 1990s. The scarcity of the empiric material, however, prevented reliable generalizations of the style characteristics. Similarly, without an in-depth study of regional variations it was impossible to produce a comprehensive picture of Ukrainian song folklore in its entirety. In this vein, an up-to-date study of Sloboda folk song traditions transgresses the regional boundaries to become a contribution to the entire picture of Ukrainian song folklore. The purpose of this article, therefore, lies in summarizing the corpus of the research material collected by the author during field studies in the Luhansk and Kharkiv 
oblasts, as well as describing the contemporary state of the Sloboda song folklore in the repertoire, genre, and performance aspects.

\section{FINDINGS}

The field research embraced Novopskov, Markivka, Milove, Bilovodsk, Starobilsk, Novoaidar, Svatove, Kreminna, Bilokurakine regions of the Luhansk oblast as well as Pervomaisk, Izium, Borova, Kupiansk, Barvinkove regions of the Kharkiv oblast. The goals of the field trip involved an in-depth study of the song repertoire of the village choirs in the given regions, mapping of various singing traditions of the Southern Sloboda, and building up a general picture of the current state and spread of folk singing traditions.

Due to the critical age of our informants and lack of those who still practice folk singing we were able to record choir singing only in five villages under study. In other cases we had to avail ourselves of solo singing and/or recording the lyrics which can be regarded as evidence of the previous spread of a given piece in the locale. This accounts for the fact that some statements in the present study are substantiated by the recordings of the traditional polyphony, whereas overall conclusions as to the spread of folk singing traditions proceed from all sources of information. The current state of the folk singing tradition in Sloboda Ukraine is characterized by the fact that most carriers of the folk singing heritage tend to be ex-members of amateur folk choirs formed around village culture clubs back in the times of the Soviet Union. Justifiably, fifty years ago this form of cultural pursuit in the country underwent professional criticism on the part of ethnomusicologists and folk singing appreciators alike, as more often than not the village country clubs promoted pop songs of the time, de novo adaptations, if not lowquality kitsch. However, with regard to the inexorable decline of the genuine folklore singing traditions the former club choirs assumed a new role of folk culture carriers and became the main source in folk culture studies, which accounts for the necessity in a more thorough attention to their present-day repertoire.

Folk choirs/gatherings fall into two distinct categories. The first comprises modern singing amateur vocal and vocal-instrumental ensembles, which include pop and kitsch. In all these cases their repertoire depends on taste and ulterior motifs. For example, one such ensemble in the village of Novobila, Novopskov region, Luhansk oblast, practices a repertoire composed of Russian and Ukrainian 'oldies' from the published scores of the Soviet time and performed to a key accordion. The teenage ensemble of v. Bondarivka, Markivka region, Luhansk oblast, ventures a polyphonic performance of folk songs, which are an inalienable part of their repertoire. The known ensembles of the village of Osynove and Bilolutsk settlement with a marked folklore tendency conduct field trips of their own in search of genuine folklore sources.

The others, mostly formed in the mid $20^{\text {th }}$ century, nowadays rarely appear on stage, their performances being mostly limited to celebrations and weekend gettogethers, where they 'sing for themselves'. Some perform only lamentations at funerals. Worthy of mention also are individual performers, who, due to old age, 
over 70 if not 80 and in poor health no longer perform in public but do remember 'old folk songs' from their youth.

We were fortunate to meet such invaluable informers in Luhansk oblast (village of Lytvinivka, Bilovodsk region, village of Kalmykivka, Milove region, village of Tytarivka, Starobilsk region), in Kharkiv oblast (village of Komarivka, Izium region, village of Dmytrivka, Pervomaisk region, village of Grushuvaha, Barvinkove region). They provided information, which enabled recording of traditional choir songs in wide use back in the $19^{\text {th }}$ century, including love songs, ballads, 'genre songs' etc.

Yet, the materials of the mentioned field trip give sufficient grounds to admit that a significant part of the song folklore, which could have been successfully recorded only a decade ago has now been irrevocably lost. Importantly, according to the old-timers' recollections and our own observations, the oblivion of folk customs accompanying such social events as weddings and calendar celebrations inevitably leads to the loss of the entire body of the relevant ritual song repertoire.

With greater ease, the informers tended to recall traditional ballads, among them: 'As I Sowed my Gherkin' («Посіяла огірочки»), 'It's a Black Sea Man, Oh Mom' («Чорноморець, мамінько»), 'Behind the Green Grove' («Поза гаєм зелененьким»), 'What a Shady Pussy-willow Grows in the Backyard', («На вгороді верба рясна»), 'A Cuckoo is Cooing at the Garden's Bottom' («Закувала зозуленька в саду на помості»), 'Lessie, Beautiful Lessie' («Дівчонка-красотка»), 'As From Behind a Cliff of Stone' («Ой з-за гори кам'яної»), 'From Behind a Dark-blue Cloud' («Із-за тучі із-за хмари»). The predominant number of performers who recollected the above-mentioned songs kept to the same or nearly the same tune. In the village of Kalmykivka they still remember and perform such century-old songs as "There is a Pond in the Fields' («Ой у полі озеречко»), 'A Crescent Moon Has Peeped out' («Зійшов місяць та й на годину»), 'There is a mound here, there is a mound there' («Ой туди гора, а відтіль друга»), 'As Nyurochka Would Go Out and along the Garden' («Ой ходила ж Нюрочка по садочку»), 'As I Sit on the Window Sill Looking Out for My Darling Seaman', («Ой сяду я край віконця виглядати Чорноморця») etc. In the village of Lytvinivka the repertoire mostly consists of the de novo adaptations of the Soviet time with a minor part from genuinely folk sources. Altogether in the Luhansk oblast we recorded over 80 folk songs, although, admittedly, most of them could be categorized as Ukrainian kitsch.

The folk repertoire in the Kharkiv oblast seems to differ to an extent from that in the Luhansk oblast. Thus, in the Kharkiv oblast none of our informers could recall the 'As From Behind a Cliff of Stone' («Ой 3-за гори кам'яної»), which is widely known in the Luhansk oblast. Conversely, 'There Stands a Birch Tree in the Fields' («А в полі береза») was easily recalled by most by most performers. In the village of Komarivka, the members of the local active folk song ensemble, who in their majority formerly sang in various amateur choirs in the Soviet time, recall that 20 or 30 years ago, they would simply get together in the open air to sing Ukrainian songs, their favorites being 'There Stands a Birch Tree in the Fields' («А в полі береза»), 'What a Shady Pussy-willow Grows in the Backyard' («На вгороді верба рясна»), 'As all the Hills Grow Green' («Усі гори зеленіють»), 'Along the Meadow, along 
the Green One' («По за лугом зелененьким»), 'A Cuckoo is Cooing at the Garden's Bottom’ («Закувала зозуленька»), 'On the Guilder Rose, on the Raspberry Bush' («На калині, на малині»), 'Along the Ravine and Along the Valley Advances a Fog' («Туман яром, туман долиною»), 'On the Other Side of The Hill’ («По той бік гора»), еtc. A similar repertoire was recorded in other villages in the Kharkiv oblast. In the village of Dmytrivka there were still living female singers formerly members of the local amateur ensemble, with whose assistance we managed to record a few traditional wedding folk songs including 'There are herbs (potion -tr.) in the hut' («А на хаті зілля»), '(Best) Friend is a (baking) a loaf' («Дружко каравай крає»), and a small number of ballads as 'Oh, Pussy-willow, Pussy-willow' («Верба верба»), 'As the Snow Has Fallen Down' («Ой упав сніжок»).

\section{DISCUSSION}

The plangent performance manner characteristic of the region pertains both to vocal and style characteristics. The older generation, aged 80-85, tend to sing andante and largamente, richly ornamenting the basic tune by means of syllable skipping, consonant voicing and vocal exclamation at the end of each stanza. This kind of singing is still practiced in the village of Kalmykivka and the village of Titarivka, Luhansk oblast.

The Lytvinivka performers, who are on average ten years younger, tend to gravitate towards a more allegro tempo and the chant less largamente, these making an impression of them following only the key turns of the tune at the expense of ornamental techniques. Not surprisingly they favor more 'energetic' songs of the Soviet time, especially so-called war songs, and the de novo ones: 'Blue are the Lilacs' («Ciрєнь голубая»), 'Digging out beet-root' , («Ой копала буряки») et al. A similar style was practiced in most villages of the Kharkiv oblast with the exception of the village of Komarivka, where they added more vocal ornamentation, often improvising with a high pitch back vocals, thus creating an articulate many tier melodic pattern.

These observations in juxtaposition with the 1970-1990 Sloboda field research lead us to believe that the marked diversity in the singing style could be linked not so much to the regional peculiarities as to the 'musical' thinking of different age groups of those who were born on the turn of the century and in the 1940s. The different singing styles which can roughly be defined as 'old' and 'new' may well be the result of the fast changing and often violent events in the $20^{\text {th }}$ century when their musical thinking was formed. The October 1917 Revolution followed by the so-called collectivization and the country's rapid industrialization could not fail to have impact on the entire generation's outlook and spiritual life promoting a new song culture which gradually ousted the traditional folklore. The famine and World War II decimated the carriers of the folk culture, thus interrupting the normal course of handing down traditional customs and rituals. In fact, the 1930-1940 generation was brought up in the realia of a new cultural and sonic environment, intentionally distanced from the cultural background. Metaphorically, this generation was brought up on the 'debris' of the ruined culture in the milieu of de novo culture and folklore new styles. 
In the light of the contrast study of the two singing styles, the singing tradition of the village of Kalmykivka is of a special interest. Located $6 \mathrm{~km}$ off the nearest motorway, the village has no direct communication with the regional center, which may account for the fact that the local style of living sustained little or no influences of modern technologies. In particular, the village's senior citizens cannot boast either mobile or land-line telephones and the bigger part of the old huts are occupied by traditional wood and coal fires. The average age of the folk ensemble is $80-87$ years. Every week they still get together for rehearsals and they are still invited to perform at traditional lamentations at funeral ceremonies. The author is indebted to the Kalmykivka ensemble for recording as many as 18 folk songs, including the century-old 'A Crescent Moon Peeped Out' («Зійшов місяць та на годину»), 'A Hill is There' («Ой туди гора»), 'As I Bathed My Feet (in the brook) Sitting on a Boulder' («На камені же ноги мила»), 'It's an Untimely Blossom of the Guelder Rose on the hill' («На горі калина ой не так розпустила»,) 'As Nyurochka Would Go Out and along the Garden' («Ой ходила ж Нюрочка по садочку»), 'As I Sit on the Window Sill Looking Out for My Darling Seaman' («Як я сяду край віконця виглядати чорноморця»), 'A Cuckoo is Cooing at the Garden's Bottom' («Закувала зозуленька в саду на помості»), 'Along the Meadow, along the Green One' («Поза лугом зелененьким»), 'What a Shady Pussy-willow Grows in the Backyard' («На вгороді верба рясна»), 'There is a Pond in the Fields' («Ой у полі озеречко»), 'As the Moon Rolled Out from Behind the Cloud' («Скотився місць із-за хмари»). Their singing is marked by a slow, restrained tempo and rich ornamentation of any prolonged note.

The folk singing style practiced in the village of Lytvinivka reveals different characteristics. With the average age of 70-75 years, the performers look on plangent songs as antiquated and 'hard' to perform. Such, in their opinion, was the at one time widely spread 'As From behind a Cliff of Stone' («Ой з-за гори кам'яної») (see appendix №3). With the verse structure of $(4+4+6) 2$, the song is similar to 'A Crescent Moon Peeped Out' («Зійшов місяць та й на годину») from the village of Kalmykivka. The rhythmic model of the song is of repetitive structure though elaborately whimsical on the account of the odd combination of beats. The tune rests on the vocally prolonged notes of the $3^{\text {rd }}$ and $5^{\text {th }}$ beats of the bar without fragmentation.

Worthy of mention is the fact that the performers found the old plangent style hard to keep to, continually attempting to accelerate the tempo.

\section{CONCLUSIONS}

1. The traditional songs still remain in the repertoire of the elderly people who had an active singing practice in youth. These rudiments disappear with the informants passing away. However the songs can still be heard in the villages far away from the main communication routes.

2. The records of the expeditions to Luhansk and Kharkiv oblasts show that none of the traditional ritual related songs remained until the present day, being replaced by the plangent folklore ballads and Soviet time songs. The 
informants could only recall the 'The Bridal Veil Cried' («Покриванка плаче») and a couple of borrowed wedding songs.

3. The amateur ensemble as a form of singing practice is preserved until these days in almost every village, but the repertoire of such ensembles has significantly changed. The folklore ensembles of the Novopskov region of Luhansk oblast are a lucky exception. Their repertoire includes traditional folk songs, which were recorded in the villages of the region in the second part of the $20^{\text {th }}$ century.

4. The style of the performance depends on the level to which the traditions have been preserved in some of the villages. The folk ensemble from the village of Kalmykivka, Milove region of Luhansk oblast, performs the traditional songs in the old style. Their plangent singing is marked with vocal ornamentation by means of syllable skipping, consonant voicing and exclamation at the end of each stanza. A different singing style was found in the village of Lytvinivka of Bilovodsk region of Luhansk oblast. The singing is less ornamented and more prone to speeding up the tempo, going through the song tiers. These singers prefer the Soviet time songs, Russian war songs and the de novo 'Blue are the Lilacs' («Сірєнь голубая»), 'Digging out beet-root' («Копала буряки»), etc.

5. The singing of the performers from the village of Komarivka of the Izium region and the village of Dmytrivka of the Pervomaisk region of Kharkiv oblast, is melodically ornamented. Even though their singing is simpler, they tend to try to 'protract' the song and get a colorific after-sound.

6. The most wide-spread songs in the Luhansk oblast, which were recorded during the research include: 'As I Sowed my Gherkin' («Посіяла огірочки»), 'It's a Black Sea Man, Oh Mom' («Чорноморець, мамінько»), 'Behind the Green Grove' («Поза гаєм зелененьким»), ‘What a Shady Pussy-willow Grows in the Backyard', («На вгороді верба рясна»), 'A Cuckoo is Cooing at the Garden's Bottom' («Закувала зозуленька в саду на помості»), 'Lessie, Beautiful Lessie' («Дівчонка-красотка»), 'As From Behind a Cliff of Stone' («Ой з-за гори кам'яної»), 'From Behind a Dark-blue Cloud' («Із-за тучі із-за хмари»). In the village of Kalmykivka of the Milove region they still remember and perform such century-old songs 'A Crescent Moon Has Peeped out' («Зійшов місяць та й на годину»), 'There is mound here, there is a mound there' («Ой туди гора, а відтіль друга»), 'As I Bathed My Feet (in the brook) Sitting on a Boulder' («На камені же ноги мила»), 'As Nyurochka Would Go Out and along the Garden' («Ой ходила ж Нюрочка по садочку»), 'As I Sit on the Window Sill Looking Out for My Darling Seaman' («Як я сяду край віконця виглядати чорноморця»), 'A Cuckoo is Cooing at the Garden's Bottom' («Закувала зозуленька в саду на помості») , 'Along the Meadow, along the Green One' («По за лугом зелененьким») and 'There is a Pond in the Fields' («Ой у полі озеречко»), 'As the Moon Rolled Out from Behind the Cloud' («Скотився місць із-за хмари»).

7. The most famous songs of the Kharkiv oblast are: 'There Stands a Birch Tree in the Fields' («А в полі береза»), 'It's a Black Sea Man, Oh Mom' («Чорноморець, мамінько»), 'What a Shady Pussy-willow Grows in the Backyard', 
(«На вгороді верба рясна»), 'As all the Hills Grow Green' («Усі гори зеленіють»), 'Along the Meadow, along the Green One' («По за лугом зелененьким»), 'A Cuckoo is Cooing at the Garden's Bottom' («Закувала зозуленька в саду на помості»), 'On the Guilder Rose, on the Raspberry Bush' («На калині, на малині»), 'Along the Ravine and Along the Valley Advances a Fog' («Туман яром, туман долиною»), 'On the Other Side of The Hill' («По той бік гора»), 'As I Sowed my Gherkin' («Посіяла огірочки»).

8. The materials gathered during the expedition to the Luhansk and Kharkiv oblasts show some of the characteristics of the song repertoire and performance traditions of the South Sloboda and clarify the diversity of traditional songs and give the feeling of the plangent performance manner of the region.

\section{REFERENCES}

Ivanov Р. (Иванов П.) (1907). Жизнь и поверья крестьян купянского уезда Харьковской губернии [Life and popular beliefs peasants Kupyansk Judetul the Kharkiv province]. Kharkiv: Pechatnoe delo.

Murzina О. (Мурзіна О.) (1995). Українська протяжна пісня в аспекті історичного часу // Зб.наукових праць кафедри фольклору та етнографії [Ukrainian lingering song in terms of historical time // Collection Scientific publications department of folklore and ethnography]. Kyiv: KDIK.

Osadcha, V. М. (Осадча В. М.) (2001). Ритмо-інтоначійна активність і манера виконання у процесі творення Слобожанського протяжного розспіву // Фольклористичні Biзï [Rhytm, intonation, and style of performance in the establishment of the Slobod plangent singing // Folkloristic visions]. Ternopil: Aston.

Potebnya А. (Потебня А. А.) (1887). Объяснения малорусских и сродных народных песен. II. Колядки и щедровки [An explanation of Little Russian and akin folk songs. P. Good wishing Christmas songs]. Warsaw: Zemkevych press. Steblianko О. (Стеблянко О.) (1965). Українські народні пісні [Ukrainian folk songs]. Kyiv: Muzyka.

Stupnitsky V. (Ступницький В.) (1929). Пісні Слобідської України [The songs of Sloboda Ukraine]. Kharkiv: DVU.

Sumtsov, M.F. (Сумцов, М. Ф.) (1918). Слобідсько-украӥнські історичні пісні [Slobodsko-Ukrainian historical songs]. Cherkasi: Siyach. 